\title{
幼児期のラダー運動遊び，サーキット遊びおよび
} 自由遊びが体力・運動能力向上に与える影響 : 内発的動機づけを重視した運動プログラムに注目して

内田 智子 $^{1}$ 大井 拓也 ${ }^{1} \quad$ 筒井清次郎 $^{2}$

\section{Effect of improvement of both physical fitness and motor ability, ladder challenge play, circuit challenge play and free-flow play in preschool children : exercise programs take free-flow play elements with emphasis on intrinsic motivation mix : a comparison study.}

\section{Tomoko Uchida', Takuya Ooi ${ }^{1}$ and Seijiro Tsutsui ${ }^{2}$}

\begin{abstract}
This study aimed to verify the effect of playing in specific exercise programs on improvement of motor ability. Various play elements with emphasis on intrinsic motivation in preschool children were introduced, and free-flow play was compared with ladder challenge play, circuit challenge play. The subjects were 76 preschool children (40 boys and 36 girls) aged 4 and 5 years old. Among the above subject, 15 consisted of a group that played ladder challenge, 31 served as the group that played with circuit challenge and 30 formed the group with free-flow.

The playing activities by the ladder challenge group included seven kinds of tasks. Playing activities by the circuit challenge group performed six kinds of tasks. They performed fundamental ability tests (25 meter dash, standing long jump, tennis-ball throw, continuous bilateral hop, self body support using both hands, ball catch, jump over and crawl under, grip strength, forward bend) .

Results were as follows.

1) In the case of 25-meter dash, the experimental the ladder challenge group \& circuit challenge group set better records than free-flow play group.

2 ) In the case of standing broad jump, the ladder challenge play \& circuit challenge group set better records than the free-flow play group. Boys set better records than girls.

3 ) In the case of jump over and crawl under, boys from circuit challenge play and ladder challenge play finish faster than those from free-flow play. On the other hand, girls from free-flow play and ladder challenge play finish faster than those from circuit challenge play.

4 ) In the same event, we can identify some significant distinction according to gender only within the experimental group of circuit challenge play. Girls finish faster than boys.

5 ) Some element of intrinsically motivated free-flow play enables children to experience multiple activities and, repetitive physical activities, without being bored.
\end{abstract}

\footnotetext{
愛知教育大学大学院教育学研究科

愛知教育大学

${ }^{1}$ Graduate School of Education, Aichi University of Education,

2 Aichi University of Education
} 
It is proved here that the physical exercise programs, which incorporate intrinsically motivated free-flow play, enhance motor ability more than free-flow play, especially in activities that contain locomotive movement pattern and manipulative movement pattern.

Key words : running ability, jumping ability, coordination, locomotive movement pattern, manipulative movement pattern

疾走能力，跳躍能力，調整力，移動系動作，操作系動作

\section{I 緒言}

世界的にみてスポーツ参加年齢は早期化傾向に あるが，心身の発達を総合的に考慮すると，小学 校になるまではスポーツに参加させない方が良い と考えられている (Smoll and Smith, 2008). 幼览 期・児童期におけるスポーツ参加は, 多様な側面 にポジティブな影響をもたらすことが期待される 反面, 親やコーチによる不適切な指導によるネガ ティブな影響として，失敗や仲間との比較による 自信や自尊心の低下，過度な競争による競技不安 の増加, 勝利追求による過度な競技ストレス体験 などの可能性が指摘されている(伊藤, 2011)。 ま た, 子どもに対する専門的なスポーツ指導の問題 点として, 成績重視の指導により, 伸び悩みや精 神的然え尽き (バーンアウト), 肉体的使い過ぎ (オーバーユース) の状況が生じている（文部科学 省, 1997)。それとは逆に, 一流選手の多くは, 幼 児期・児童期には専門化されたスポーツとしてで はなく, 遊びとして多くの運動を経験しているこ とも明らかにされている (中本, 2011). したがっ て，子どもの運動指導を行うのであれば，特定の スポーツ指導ではなく, 多様な動きを経験させる 運動遊びを取り入れるべきである.

幼稚園における保育時間内の運動指導の実施と 運動能力との関係について, 杉原ほか（2010）は 運動指導していない園, 運動指導頻度が高い園と 低い園の 3 群に分け比較したところ, 最も運動能 力が高いのは指導していない園であり, 次いで指 導頻度の低い園となり, 最も運動能力が低いのは 指導頻度の高い園であったと報告している。この 結果は, 2002 年および 2008 年調査結果（吉田ほ か, 2004 ; 森ほか, 2011）においても, 同様の結 果であった（杉原ほか，2010）。この理由として,
指導内容と方法から 2 つの可能性が指摘されてい る (杉原, 2014b).1つ目は, 運動指導では体操, 水泳, サッカー等の特定の種目が挙げられている ことが多く（杉原ほか, 2004：吉田ほか, 2007）, 種目に限定された偏った活動しかしていない可能 性である.2つ目には, 整列にはじまり, 準備運 動, 説明, 順番待ちなどの指導者主体の画一的な 指導形態が用いられており, 子どもの運動時間が 少ない可能性である.

また，運動を，一斉指導としてではなく，子ど もの遊びとして行っている程度が高いほど, 幼児 の運動パターンが多様であり, その出現頻度も高 いことが報告されている（杉原ほか, 2011）。これ らのことから, 幼児に対しての運動プログラムは, 小・中学生に行われることの多い上達を目指した 運動技術の一斉指導や体力づくりを目指す指導者 主導型であればあるほど, 運動能力が低く, 運動 パターンも少なくなることを示している（杉原， 2014b).

次に, 吉田ほか（2015）は，子ども自身によっ て運動遊びが決定される傾向が高い群と指導者に よって決定される傾向が高い群，両群の中間的な 傾向を示す群を比較したところ, 子ども自身が決 定する傾向の高い群の方が, 出現する運動パター ンが多く，その出現頻度も高いことを明らかにし ている. しかし，指導者によって決定される傾向 が高い群においては，運動能力が高い子どもにお いて出現頻度が高い基礎的運動パターン 6 種(「逆 立ちする」「持ち上げる」「押す」「運ぶ，動かす」 「まわす」「ころがす」）が含まれていた。 また， 3 歳児においては, 指導者によって決定される傾向 の高い群の方が，子ども自身によって決定される 傾向が高い群よりも, 出現頻度の高い運動能力パ ターンが多くみられたことも報告されている。し 
たがって, 子どもだけの遊びでは出現しにくい運 動パターンもあり, 指導者によって多様な運動パ ターン学習の場を提供する必要性も示唆される.

したがって, 上達を目指した運動技術の一齐指 導は必要ではないものの, 放任的に子どもだけで 自由に遊ばせれば十分でもない。幼児期の運動指 導者は子どもの主体的で自己決定による運動遊び ができるように，子どもが遊びたくなる環境づく りを工夫することや子どもだけでは気づかない運 動遊びを取り入れ, 多種多様な運動パターンを経 験させる必要があると考えられる。

杉原 (2014a) は, 遊びは内発的に動機づけられ た活動でなければならないとしている。内発的動 機づけは挑戦的な事態を克服することによって自 己の能力を向上させる行動と, 獲得して現在自分 が持っている能力を最大限に発揮するという 2 種 類の行動を引き起こすとされている（Deci, 1980). Deci and Ryan（1985）は, 内発的動機づ けを高める要因は, 自己有能感, 自律性, 関係性 としており,これら 3 要素を取り入れた取り組み が幼児の運動指導には不可欠であると考えられ る. 杉原 (2014a) は, 幼児期の子どもは褒められ たいとか友達と仲良くしたいという外発的自発性 で活動を始めるうちに，活動を継続する経過の中 で, 挑戦すること, 工夫すること, 上達すること など, 内発的に動機づけられ，集められなくても， 友達がやらなくても自己決定的に一生懸命取り組 むことが少なくないと述べている。したがって， 内発的動機づけを意識した指導方法は子どもが主 体的に活動を実施し, 多様な動作パターンを出現 させると考えられる. 幼览のための運動プログラ ムが, 活動内容および場所, 頻度, 順序, 時間に おいて細かく設定しプログラム化すればするほ ど, 遊びの要素は少なくなってしまう。したがっ て, 杉原 $(2014 b)$ は, 子どもの経験や興味・関心 に合わせて，いくつかの選択肢を示して子どもた ちがやりたいことを決められるようにすることを 提案している.

運動コントロール能力を高めるために, 多様な 運動パターンやバリエーションを引き出す視点と して, 施設・用具の多様性と柔軟な使用はその一 つである（近藤, 1995)。尒ども遊びを通して対 象物と身体で関わることにより, 物の性質や仕組
みに気づき，いろいろ試したり工夫したりして活 動することによって, 運動好奇心や知的発達を刺 激し, 多様な動作が経験されることにつながる. そこで, 複数の施設・用具を組み合わせたサーキッ 卜遊びにおいて, 固定的な使用方法を限定せず, 幼児の運動の発想力を活かした指導方法であれ ば，複数の動作や多様な運動パターンを経験させ ることが可能であると考えられる.

また，宮口ほか（2010）は幼児期においては， 走能力を高める運動遊びの一つとしてラダー運動 が有効であると報告している。しかし，宮口ほか の研究では, 走能力以外の跳能力や投能力, 他の 運動課題に及ぼす効果に関しては検証されていな い.

そこで本研究では，指導者が関与せず，子ども 自身が好きな遊びを選択して遊ぶ自由遊びの方 が，いかなる運動指導よりも体力・運動能力を高 めるのか, それとも, 内発的動機づけを重視した 多様な課題を経験させる運動指導であれば，指導 者が関与しない自由遊びよりも体力・運動能力を 高めることができるのか, を明らかにすることを 目的とする. 具体的には, 多様な運動課題が提供 できるサーキット遊び，ラダーを用いた運動遊び と, 指導者が関与しない自由遊びが, 体力・運動 能力に及ぼす影響を比較する.

\section{II 方 法}

\section{1. 対象者}

$\mathrm{S}$ 幼稚園に所属する幼稚園年中児 76 名（男児 40 名, 女览 36 名）が対象であった．対象者の月 齢の平均值は $55.7 \pm 3.8$ 歳であった。

対象の幼稚園園長および副園長, クラス担任, 保護者には実験内容を直接又は配付資料によって 説明し，承諾を得た。対象児に関するデータは ID 番号で管理した。また，測定および運動遊び 前には，対象児の体調が万全であることを確認し て実施した。

\section{2. 期 間}

2015 年 4 月上旬から 8 月下旬に行われた. 


\section{3. 群分け}

（1）ラダー群：幼览でもスムーズなフットワー クができるように監修された「チビラダー (DANNO WORKS，大阪)」を使用し，ラダー運動 を行う群 15 名 (男児 7 名, 女览 8 名).

（2）サーキット群：6 種類の運動を組み合わせ たサーキット運動を行う群 31 名（男児 18 名, 女 児 13 名).

（3）自由遊び群：自由な遊びを行う群 30 名（男 児 15 名, 女巟 15 名).

\section{4. 指導環境および方法}

(1) ラダー群

子どもが安心して運動遊びに取り組めるよう, 日常的に使用している遊戯室にて実施した。その ため, 施設内には, 常設してあるクッションやフ ラフープ等の小型遊具が自由に使用できる環境下 であった，動作方法については，指導者が子ども に示範を見せた後, やりたい課題を子どもに選択 させ, 順序も子どもに決定させた.

(2) サーキット群

子どもが安心して運動遊びに取り組めるよう, 日常的に運動遊び時に使用している体育館にて実 施した．動作方法については，指導者が子どもに 示範を見せた後, 課題の開始順序, 及び，やりた い方法を子どもに決めさせた。

(3) 自由遊び群

室内遊びとして, ままごと, 絵本を読む, 絵を 描く, ブロック遊び, 塗絵, 粘土制作等が一般的 に見られる教材を使用できる環境であった。屋外 遊びでは, 固定遊具, 砂場, 三輪車, ボール遊び の他，虫取りカゴを制作したことから保育者の援 助活動として主に虫取りが行われていた。これら の環境下において運動課題の設定はせずに自由に 遊ばせることとした。

なお, いずれの群の活動時間も 60 分間とし, 頻 度は週 2 回 4 週間の計 8 回とした.

\section{5. 実験課題}

いずれも運動遊びとして成立できるよう，子ど もの自由な行動を認めながら安全が確保できる範 囲内で行わせ，訓練的な反復にならないように配 慮した。
内発的動機付けを高める要因として, 自己有能 感，自律性，関係性を含められるよう指導援助を 行った，自己有能感については，種目の終わりに はポーズを決める箇所を用意し，子どもが種目を 終えポーズを決めた時に褒める言葉をかけること とした。

自律性では, 各種目の課題設定について進行方 向と進行するための方法のみを規定し, 子どもが 設定した模倣遊びを中心として動作様式は子ども に自己決定させた．また，水分補給や休憩と再開 のタイミングは子ども自身の判断によるものとし た．関係性については，開始する種目は子どもの 仲間同士で決定させることとし，サーキット群の 網くぐりの課題については協力的に実施できるよ うに援助した。

\section{（1）ラダー群}

青少年や競技者用の SAQ（Speed/スピード， Agility/敏捷性, Quickness/すばやさ）ドリル（日 本 SAQ 協会) の中から, 幼児でも成就可能と考え られる難易度の異なる以下の課題を選択した。

(1)歩行：1 マスに対し 1 歩ずつのステップで前 進する.

(2)かけ足：1 マスに対し 1 歩ずつのステップで かけ足で前進する.

(3)グーパージャンプ：1 マスごとに, 両足を閉 じる・開く動作を行い, 前向きにジャンプして前 進する.

(4)こびとスキップ：1 マスで 1 回ずつ，できる だけ速く細かいスキップをしながら 1 マスずつ前 進する。

(5)スラロームジャンプ: 正面を向き, 左右の紐 を交互に 1 マスずつ両足同時にジャンプして前進 する。

(6)ケンパジャンプ: 正面を向き, ケン・パのス テップで1マスずつ前進する.

(7)ひねりジャンプ: 横向きになり, ラダーの 1 方の縁をまたぐ位置からスタートし, ジャンプし て身体を 180 度回転させながら，次のマスの縁を またぐ位置に着地する。この動作をできるだけ速 く連続していく.

(2) サーキット群

(1)マット運動：幼児がやりたい回転系運動を行 い前進する（写真 1). 


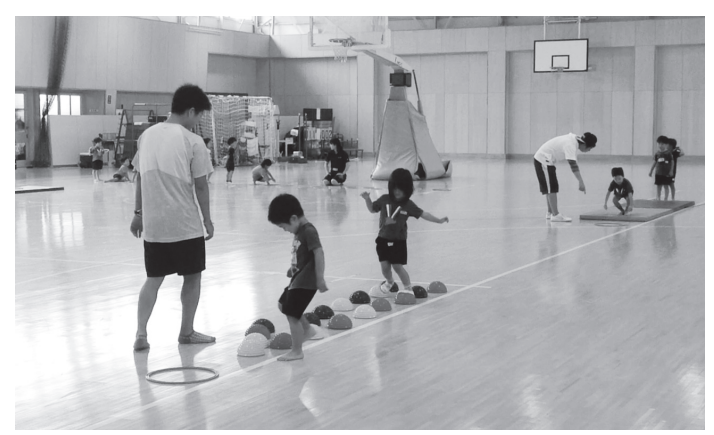

写真 1 マット\&フットドーム

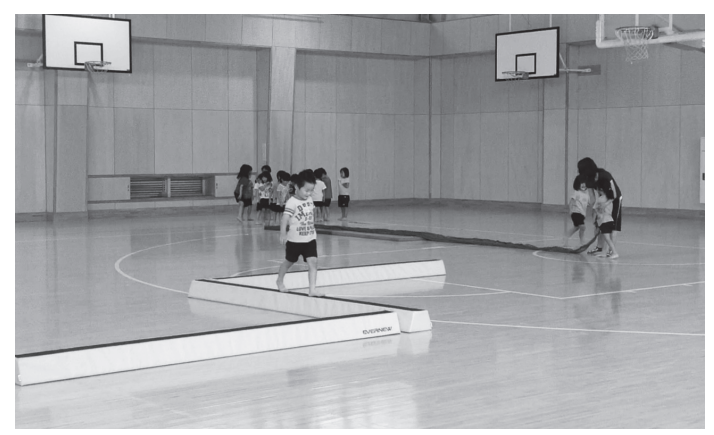

写真 3 平均台

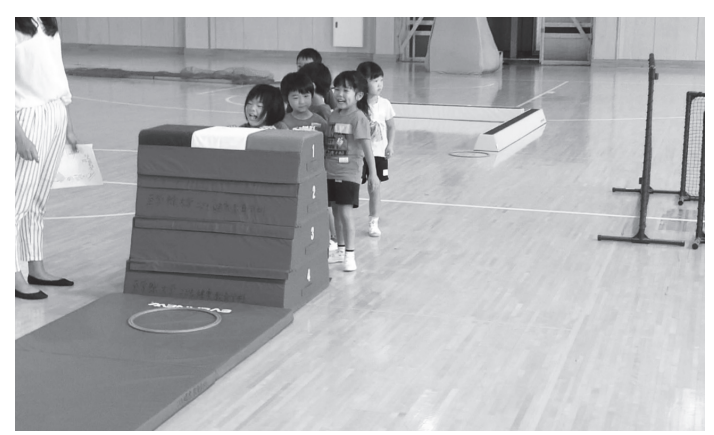

写真 5 跳び箱

(2)フットドーム：表面に凹凸のあるフットドー ムを 2 列に並べ，フットドームの上を手と足をの せて渡る（写真 1).

(3)円盤 4 足歩行 : 直径 $30 \mathrm{~cm}$ 程の円盤マットを 並べ，その上に手足を乗せながら 4 足歩行を行う (写真 2).

(4)平均台: 高さの違う平均台 3 台を $\mathrm{S}$ 字に並 べ, その上を歩く (写真 3).

(5)網くぐり:網の四隅を順番に仲間同士で抑え， 網の下をくぐり抜ける (写真 4).

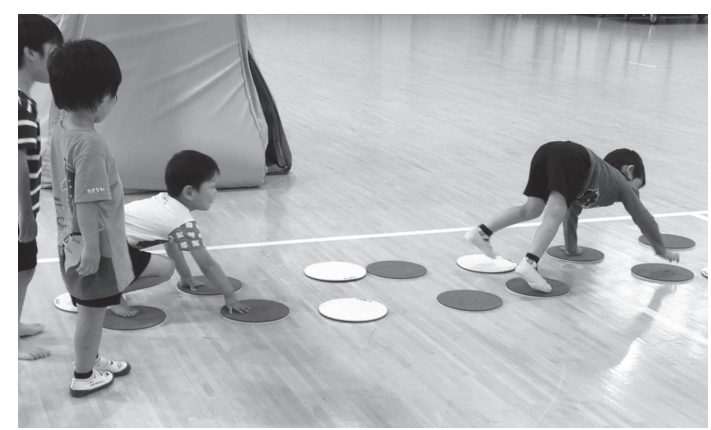

写真 2 円盤 4 足歩行

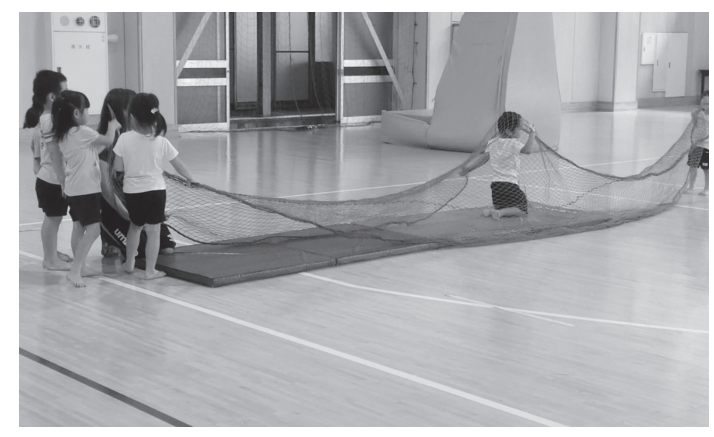

写真 4 網くぐり

6)跳び箱：跳び箱によじ登り，下に敷いてある マットの上に跳び下りる（写真 5).

\section{6. 体力 ・運動能力測定}

運動プログラム開始前日と運動プログラム終了 3 日後に, MKS 幼児運動能力検査 (幼児運動能力 研究会, 2011）および新体力テストを行い, それ ぞれプレテストとポストテストとした。

(1) $25 \mathrm{~m}$ 走

(2)立ち幅跳び

(3)テニスボール投げ

(4)両足連続跳び越し

(5)体支持持続時間

(6)捕球

(7)跳び越しくぐり

(8)握力

(9)長座体前屈

\section{7. 分析方法}

1) プレテストとポストテスト

プレテストについて, 群（3）と性（2）の二要 
表 1 群別, 性別にみたプレテストの平均値と標準偏差及び 2 要因分散分析の結果

\begin{tabular}{|c|c|c|c|c|c|}
\hline 運動能力測定項目 & 群 & 性 & 人数 & $\begin{array}{c}\text { プレテスト } \\
\text { 平均値士標準偏差 }\end{array}$ & $\begin{array}{l}\text { 主効果及び } \\
\text { 交互作用 }\end{array}$ \\
\hline \multirow{3}{*}{25 m 走（秒） } & ラダー & $\begin{array}{l}\text { 男子 } \\
\text { 女子 }\end{array}$ & $\begin{array}{l}7 \\
8\end{array}$ & $\begin{array}{l}6.5 \pm 0.7 \\
7.1 \pm 1.2\end{array}$ & \multirow{3}{*}{$\begin{array}{l}\text { 群の主効果 } \\
\text { あり }\end{array}$} \\
\hline & サーキット & $\begin{array}{l}\text { 男子 } \\
\text { 女子 }\end{array}$ & $\begin{array}{l}18 \\
13\end{array}$ & $\begin{array}{l}7.0 \pm 0.6 \\
7.6 \pm 0.7\end{array}$ & \\
\hline & 自由遊び & $\begin{array}{l}\text { 男子 } \\
\text { 女子 }\end{array}$ & $\begin{array}{l}15 \\
15 \\
\end{array}$ & $\begin{array}{l}7.9 \pm 1.2 \\
7.6 \pm 0.8\end{array}$ & \\
\hline \multirow{3}{*}{ 立ち幅跳び（m） } & ラダー & $\begin{array}{l}\text { 男子 } \\
\text { 女子 }\end{array}$ & $\begin{array}{l}7 \\
8\end{array}$ & $\begin{array}{l}99.4 \pm 19.2 \\
75.6 \pm 30.4\end{array}$ & \multirow{3}{*}{$\begin{array}{l}\text { 群の主効果 } \\
\text { 性の主効果 } \\
\text { あり }\end{array}$} \\
\hline & サーキット & $\begin{array}{l}\text { 男子 } \\
\text { 女子 }\end{array}$ & $\begin{array}{l}18 \\
13\end{array}$ & $\begin{array}{l}77.5 \pm 21.1 \\
65.0 \pm 17.3\end{array}$ & \\
\hline & 自由遊び & $\begin{array}{l}\text { 男子 } \\
\text { 女子 }\end{array}$ & $\begin{array}{l}15 \\
15\end{array}$ & $\begin{array}{l}71.7 \pm 17.3 \\
74.0 \pm 14.4\end{array}$ & \\
\hline \multirow{3}{*}{ テニスボール投げ（m） } & ラダー & $\begin{array}{l}\text { 男子 } \\
\text { 女子 }\end{array}$ & $\begin{array}{l}7 \\
8\end{array}$ & $\begin{array}{c}14.2 \pm 27.4 \\
3.0 \pm 0.7\end{array}$ & \multirow{3}{*}{$\begin{array}{l}\text { 性の主効果 } \\
\text { あり }\end{array}$} \\
\hline & サーキット & $\begin{array}{l}\text { 男子 } \\
\text { 女子 }\end{array}$ & $\begin{array}{l}18 \\
13\end{array}$ & $\begin{array}{l}4.0 \pm 1.2 \\
2.8 \pm 1.1\end{array}$ & \\
\hline & 自由遊び & $\begin{array}{l}\text { 男子 } \\
\text { 女子 }\end{array}$ & $\begin{array}{l}15 \\
15\end{array}$ & $\begin{array}{l}3.9 \pm 1.3 \\
3.2 \pm 1.0\end{array}$ & \\
\hline \multirow{3}{*}{ 両足連続跳び越し（秒） } & ラダー & $\begin{array}{l}\text { 男子 } \\
\text { 女子 }\end{array}$ & $\begin{array}{l}7 \\
8\end{array}$ & $\begin{array}{l}6.0 \pm 1.9 \\
6.4 \pm 0.8\end{array}$ & \multirow{3}{*}{$\begin{array}{l}\text { 群の主効果 } \\
\text { あり }\end{array}$} \\
\hline & サーキット & $\begin{array}{l}\text { 男子 } \\
\text { 女子 }\end{array}$ & $\begin{array}{l}18 \\
13\end{array}$ & $\begin{array}{l}7.6 \pm 2.5 \\
8.4 \pm 2.6\end{array}$ & \\
\hline & 自由遊び & $\begin{array}{l}\text { 男子 } \\
\text { 女子 }\end{array}$ & $\begin{array}{l}15 \\
15 \\
\end{array}$ & $\begin{array}{l}9.3 \pm 4.1 \\
9.7 \pm 4.3\end{array}$ & \\
\hline \multirow{3}{*}{ 体支持持続時間（秒） } & ラダー & $\begin{array}{l}\text { 男子 } \\
\text { 女子 }\end{array}$ & $\begin{array}{l}7 \\
8\end{array}$ & $\begin{array}{l}12.4 \pm 6.7 \\
16.0 \pm 14.8\end{array}$ & \\
\hline & サーキット & $\begin{array}{l}\text { 男子 } \\
\text { 女子 }\end{array}$ & $\begin{array}{l}18 \\
13\end{array}$ & $\begin{array}{r}10.4 \pm 9.5 \\
7.4 \pm 6.2 \\
\end{array}$ & \\
\hline & 自由遊び & $\begin{array}{l}\text { 男子 } \\
\text { 女子 }\end{array}$ & $\begin{array}{l}15 \\
15\end{array}$ & $\begin{array}{l}10.5 \pm 8.9 \\
13.2 \pm 6.8\end{array}$ & \\
\hline \multirow{3}{*}{ 捕球（回） } & ラダー & $\begin{array}{l}\text { 男子 } \\
\text { 女子 } \\
\end{array}$ & $\begin{array}{l}7 \\
8\end{array}$ & $\begin{array}{l}4.2 \pm 4.7 \\
4.0 \pm 3.4\end{array}$ & \\
\hline & サーキット & $\begin{array}{l}\text { 男子 } \\
\text { 女子 } \\
\end{array}$ & $\begin{array}{l}18 \\
13 \\
\end{array}$ & $\begin{array}{l}3.9 \pm 2.0 \\
3.5 \pm 2.7\end{array}$ & \\
\hline & 自由遊び & $\begin{array}{l}\text { 男子 } \\
\text { 女子 }\end{array}$ & $\begin{array}{l}15 \\
15 \\
\end{array}$ & $\begin{array}{l}4.0 \pm 2.9 \\
4.2 \pm 2.8 \\
\end{array}$ & \\
\hline \multirow{3}{*}{ 跳び越しくぐり（秒） } & ラダー & $\begin{array}{l}\text { 男子 } \\
\text { 女子 }\end{array}$ & $\begin{array}{l}7 \\
8 \\
\end{array}$ & $\begin{array}{l}25.4 \pm 7.7 \\
26.9 \pm 8.1\end{array}$ & \\
\hline & サーキット & $\begin{array}{l}\text { 男子 } \\
\text { 女子 }\end{array}$ & $\begin{array}{l}18 \\
13 \\
\end{array}$ & $\begin{array}{l}27.1 \pm 8.5 \\
28.3 \pm 8.0 \\
\end{array}$ & \\
\hline & 自由遊び & $\begin{array}{l}\text { 男子 } \\
\text { 女子 }\end{array}$ & $\begin{array}{l}15 \\
15 \\
\end{array}$ & $\begin{array}{l}29.5 \pm 9.6 \\
30.2 \pm 8.3 \\
\end{array}$ & \\
\hline \multirow{3}{*}{ 握力（kg） } & ラダー & $\begin{array}{l}\text { 男子 } \\
\text { 女子 }\end{array}$ & $\begin{array}{l}7 \\
8 \\
\end{array}$ & $\begin{array}{l}5.3 \pm 2.0 \\
5.0 \pm 2.0 \\
\end{array}$ & \\
\hline & サーキット & $\begin{array}{l}\text { 男子 } \\
\text { 女子 }\end{array}$ & $\begin{array}{l}18 \\
13\end{array}$ & $\begin{array}{l}5.9 \pm 1.7 \\
5.5 \pm 2.4\end{array}$ & \\
\hline & 自由遊び & $\begin{array}{l}\text { 男子 } \\
\text { 女子 }\end{array}$ & $\begin{array}{l}15 \\
15 \\
\end{array}$ & $\begin{array}{l}5.7 \pm 1.7 \\
5.7 \pm 2.1 \\
\end{array}$ & \\
\hline \multirow{3}{*}{ 長座体前屈（cm） } & ラダー & $\begin{array}{l}\text { 男子 } \\
\text { 女子 }\end{array}$ & $\begin{array}{l}7 \\
8 \\
\end{array}$ & $\begin{array}{l}19.5 \pm 3.4 \\
21.0 \pm 10.4\end{array}$ & \\
\hline & サーキット & $\begin{array}{l}\text { 男子 } \\
\text { 女子 }\end{array}$ & $\begin{array}{l}18 \\
13 \\
\end{array}$ & $\begin{array}{l}20.4 \pm 4.9 \\
21.2 \pm 3.9\end{array}$ & \\
\hline & 自由遊び & $\begin{array}{l}\text { 男子 } \\
\text { 女子 }\end{array}$ & $\begin{array}{l}15 \\
15\end{array}$ & $\begin{array}{l}22.7 \pm 3.8 \\
22.4 \pm 4.8\end{array}$ & \\
\hline
\end{tabular}


因分散分析を行い，平均值を比較した.

2 ）共変量分散分析

プレテストにおいて, 表 1 に示すように性差や 群間差がみられるために，プレテストを共変量と する群（3）と性（2）の二要因共変量分散分析を 行い, ポストテストの調整後の平均值を比較した. また，下位検定には，フィッシャーの LSD 検定に よる多重比較を用いた。なお，統計的有意水準は 5\%とした。

\section{III 結 果}

\section{1. 身体特性}

ラダー群の身体特性は, 身長が $103.7 \pm 16.4$ $\mathrm{cm}$, 体重は $16.4 \pm 1.6 \mathrm{~kg}$ であった。 サーキット 群の身体特性は, 身長が $102.3 \pm 16.4 \mathrm{~cm}$, 体重は $16.5 \pm 1.5 \mathrm{~kg}$ であった。自由遊び群の身体特性 は，身長が $103.5 \pm 4.4 \mathrm{~cm}$, 体重は $16.9 \pm 2.1 \mathrm{~kg}$ であった，等分散検定を行った結果，身長におい て, 群の主効果 $(\mathrm{F}(2,74)=0.365, \mathrm{p}>.05)$ は 有意でなかった。体重においても, 群の主効果 $(\mathrm{F}$ $(2,74)=0.444, \mathrm{p}>.05)$ は有意でなかった. し たがって,群間に身体特性の差は無いとみなした。

\section{2. プレテスト}

表 1 に群別, 性別にみたプレテストの平均值と 標準偏差, 及び，分散分析の結果を示した。

$25 \mathrm{~m}$ 走において, 群の主効果 $(\mathrm{F}(2,68)=5.503$, $\mathrm{p}<.01$ ) は有意であったが, 性の主効果（F（1, $68)=2.125, \mathrm{p}>.05)$ と交互作用 $(\mathrm{F}(2,68)=$ $2.759, \mathrm{p}>.05)$ は有意でなかった.

立ち幅跳びにおいて, 群の主効果 $(\mathrm{F}(2,68)=$ $3.770, \mathrm{p}<.05)$ と性の主効果 $(\mathrm{F}(1,68)=5.580$, $\mathrm{p}<.05)$ は有意であったが, 交互作用 $(\mathrm{F}(2,68)$ $=2.442, \mathrm{p}>.05 ）$ は有意でなかった.

テニスボール投げにおいて, 性の主効果 $(\mathrm{F}$ (1, 69) $=4.091, \mathrm{p}<.05 ）$ は有意であったが, 群の主 効果 $(\mathrm{F}(2,69)=2.012, \mathrm{p}>.05)$ と交互作用 $(\mathrm{F}$ $(2,69)=2.067, \mathrm{p}>.05)$ は有意でなかった.

両脚連続跳び越しにおいて, 群の主効果 $(\mathrm{F}(2$, $70)=5.585, \mathrm{p}<.01 ）$ は有意であったが, 性の主 効果 $(\mathrm{F}(1,70)=0.469, \mathrm{p}>.05)$ と交互作用 $(\mathrm{F}$ $(2,70)=0.036, \mathrm{p}>.05)$ は有意でなかった.
体支持持続時間において, 群の主効果（F（2， $65)=1.958, \mathrm{p}>.05)$ と性の主効果 $(\mathrm{F}(1,65)=$ $0.258, \mathrm{p}>.05)$ 及び, 交互作用 $(\mathrm{F}(2,65)=1.016$, $\mathrm{p}>$.05）のいずれも有意でなかった.

捕球に扔いて, 群の主効果 $(\mathrm{F}(2,68)=0.133$, $\mathrm{p}>.05)$ と性の主効果 $(\mathrm{F}(1,68)=0.029, \mathrm{p}>$ .05) 及び，交互作用 $(\mathrm{F}(2,68)=0.081, \mathrm{p}>.05)$ のいずれも有意でなかった。

跳び越しくぐりにおいて, 群の主効果（F（2, $68)=1.041, \mathrm{p}>.05)$ と性の主効果 $(\mathrm{F}(1,68)=$ $0.292, \mathrm{p}>.05)$ 及び, 交互作用 $(\mathrm{F}(2,68)=0.013$, $\mathrm{p}>$.05）のいずれも有意でなかった.

握力において, 群の主効果 $(\mathrm{F}(2,70)=0.463$, $\mathrm{p}>.05)$ と性の主効果 $(\mathrm{F}(1,70)=0.310, \mathrm{p}>$ .05）及び，(交互作用 $\mathrm{F}(2,70)=0.072, \mathrm{p}>.05)$ のいずれも有意でなかった。

長座体前屈において, 群の主効果 $(F(2,70)=$ $1.337, \mathrm{p}>.05)$ と性の主効果 $(\mathrm{F}(1,70)=0.273$, $\mathrm{p}>.05)$ 及び, (交互作用 $\mathrm{F}(2,70)=0.182, \mathrm{p}>$ .05）のいずれも有意でなかった.

いくつかの種目のプレテストにおいて, 群間差 や性差がみられた。

\section{3. 共変量分散分析}

プレテストに差がみられたことから，プレテス 卜を共变量とした共変量分散分析を行った。表 2 に男女別，群別にみたポストテストの調整後の平 均值と標準偏差, 及び, 共変量分散分析の結果を 示した.

$25 \mathrm{~m}$ 走において, 群の主効果 $(\mathrm{F}(2,61)=6.849$, $\mathrm{p}<.01$ ) は有意であったが, 性の主効果（F（1, $61)=0.526, \mathrm{p}>.05)$ と交互作用 $(\mathrm{F}(2,61)=$ $0.062, \mathrm{p}>.05)$ は有意でなかった。 そこで, 群 の多重比較を行った結果, 自由遊び群よりもラ ダー群とサーキット群の方が速く走るようになっ た（図 1).

立ち幅跳びにおいて, 群の主効果 $(F(2,64)=$ $10.113, \mathrm{p}<.01)$ は有意であったが, 性の主効果 $(\mathrm{F}(1,64)=2.630, \mathrm{p}<.05)$ と交互作用（F（2, $64)=0.166, \mathrm{p}>.05 ）$ は有意でなかった。 そこで, 群の多重比較を行った結果, 自由遊び群よりも サーキット群とラダー群の方が遠くへ跳ぶように なった（図 2). 
表 2 群別, 性別にみたポストテストの平均値と標準偏差及び 2 要因共変量分散 分析の結果

\begin{tabular}{|c|c|c|c|c|c|}
\hline 運動能力測定項目 & 群 & 性 & 人数 & $\begin{array}{c}\text { 調整後 } \\
\text { 平均値土標準偏差 }\end{array}$ & $\begin{array}{l}\text { 共変量分散 } \\
\text { 分析の結果 }\end{array}$ \\
\hline \multirow{3}{*}{$25 \mathrm{~m}$ 走（秒） } & ラダー & $\begin{array}{l}\text { 男子 } \\
\text { 女子 }\end{array}$ & $\begin{array}{l}7 \\
8\end{array}$ & $\begin{array}{l}6.9 \pm 0.7 \\
7.0 \pm 0.6\end{array}$ & \multirow{3}{*}{$\begin{array}{l}\text { 群の主効果 } \\
\text { あり }\end{array}$} \\
\hline & サーキット & $\begin{array}{l}\text { 男子 } \\
\text { 女子 }\end{array}$ & $\begin{array}{l}18 \\
13\end{array}$ & $\begin{array}{l}6.8 \pm 0.7 \\
6.8 \pm 0.7\end{array}$ & \\
\hline & 自由遊び & $\begin{array}{l}\text { 男子 } \\
\text { 女子 }\end{array}$ & $\begin{array}{l}15 \\
15\end{array}$ & $\begin{array}{l}7.4 \pm 0.7 \\
7.5 \pm 0.6\end{array}$ & \\
\hline \multirow{3}{*}{ 立ち幅跳び（m） } & ラダー & $\begin{array}{l}\text { 男子 } \\
\text { 女子 }\end{array}$ & $\begin{array}{l}7 \\
8\end{array}$ & $\begin{array}{r}100.6 \pm 13.6 \\
96.6 \pm 12.6\end{array}$ & \multirow{3}{*}{$\begin{array}{l}\text { 群の主効果 } \\
\text { あり }\end{array}$} \\
\hline & サーキット & $\begin{array}{l}\text { 男子 } \\
\text { 女子 }\end{array}$ & $\begin{array}{l}18 \\
13\end{array}$ & $\begin{array}{l}92.5 \pm 12.6 \\
88.3 \pm 11.7\end{array}$ & \\
\hline & 自由遊び & $\begin{array}{l}\text { 男子 } \\
\text { 女子 }\end{array}$ & $\begin{array}{l}15 \\
15\end{array}$ & $\begin{array}{l}84.5 \pm 12.7 \\
76.8 \pm 12.6\end{array}$ & \\
\hline \multirow{3}{*}{ テニスボール投げ（m） } & ラダー & $\begin{array}{l}\text { 男子 } \\
\text { 女子 }\end{array}$ & $\begin{array}{l}7 \\
8\end{array}$ & $\begin{array}{l}6.2 \pm 1.5 \\
3.4 \pm 2.6\end{array}$ & \multirow{3}{*}{$\begin{array}{l}\text { 性の主効果 } \\
\text { あり }\end{array}$} \\
\hline & サーキット & $\begin{array}{l}\text { 男子 } \\
\text { 女子 }\end{array}$ & $\begin{array}{l}18 \\
13\end{array}$ & $\begin{array}{l}5.7 \pm 1.6 \\
4.0 \pm 2.5\end{array}$ & \\
\hline & 自由遊び & $\begin{array}{l}\text { 男子 } \\
\text { 女子 }\end{array}$ & $\begin{array}{l}15 \\
15 \\
\end{array}$ & $\begin{array}{l}5.2 \pm 1.9 \\
3.9 \pm 2.3 \\
\end{array}$ & \\
\hline \multirow{3}{*}{ 両足連続飛び越し（秒） } & ラダー & $\begin{array}{l}\text { 男子 } \\
\text { 女子 }\end{array}$ & $\begin{array}{l}7 \\
8\end{array}$ & $\begin{array}{l}5.4 \pm 2.4 \\
6.1 \pm 2.4\end{array}$ & \\
\hline & サーキット & $\begin{array}{l}\text { 男子 } \\
\text { 女子 }\end{array}$ & $\begin{array}{l}18 \\
13 \\
\end{array}$ & $\begin{array}{l}6.2 \pm 2.4 \\
6.9 \pm 2.3 \\
\end{array}$ & \\
\hline & 自由遊び & $\begin{array}{l}\text { 男子 } \\
\text { 女子 }\end{array}$ & $\begin{array}{l}15 \\
15 \\
\end{array}$ & $\begin{array}{l}7.8 \pm 2.4 \\
6.4 \pm 2.4 \\
\end{array}$ & \\
\hline \multirow{3}{*}{ 体支持持続時間（秒） } & ラダー & $\begin{array}{l}\text { 男子 } \\
\text { 女子 }\end{array}$ & $\begin{array}{l}7 \\
8\end{array}$ & $\begin{array}{l}13.0 \pm 7.5 \\
12.7 \pm 7.6\end{array}$ & \\
\hline & サーキット & $\begin{array}{l}\text { 男子 } \\
\text { 女子 }\end{array}$ & $\begin{array}{l}18 \\
13 \\
\end{array}$ & $\begin{array}{l}13.5 \pm 7.5 \\
16.8 \pm 7.6 \\
\end{array}$ & \\
\hline & 自由遊び & $\begin{array}{l}\text { 男子 } \\
\text { 女子 }\end{array}$ & $\begin{array}{l}15 \\
15\end{array}$ & $\begin{array}{l}10.7 \pm 7.5 \\
10.4 \pm 7.5\end{array}$ & \\
\hline \multirow{3}{*}{ 捕球（回） } & ラダー & $\begin{array}{l}\text { 男子 } \\
\text { 女子 }\end{array}$ & $\begin{array}{l}7 \\
8\end{array}$ & $\begin{array}{l}7.2 \pm 2.4 \\
6.5 \pm 2.4\end{array}$ & \multirow{3}{*}{$\begin{array}{l}\text { 群の主効果 } \\
\text { あり }\end{array}$} \\
\hline & サーキット & $\begin{array}{l}\text { 男子 } \\
\text { 女子 }\end{array}$ & $\begin{array}{l}18 \\
13\end{array}$ & $\begin{array}{l}5.1 \pm 2.5 \\
3.8 \pm 2.5\end{array}$ & \\
\hline & 自由遊び & $\begin{array}{l}\text { 男子 } \\
\text { 女子 }\end{array}$ & $\begin{array}{l}15 \\
15\end{array}$ & $\begin{array}{l}3.5 \pm 2.5 \\
4.8 \pm 2.5\end{array}$ & \\
\hline \multirow{3}{*}{ 跳び越しくぐり（秒） } & ラダー & $\begin{array}{l}\text { 男子 } \\
\text { 女子 }\end{array}$ & $\begin{array}{l}7 \\
8\end{array}$ & $\begin{array}{l}22.7 \pm 6.0 \\
25.2 \pm 6.0\end{array}$ & \multirow{3}{*}{$\begin{array}{l}\text { 群と性の } \\
\text { 交互作用あり }\end{array}$} \\
\hline & サーキット & $\begin{array}{l}\text { 男子 } \\
\text { 女子 }\end{array}$ & $\begin{array}{l}18 \\
13\end{array}$ & $\begin{array}{l}26.1 \pm 6.0 \\
33.6 \pm 6.0\end{array}$ & \\
\hline & 自由遊び & $\begin{array}{l}\text { 男子 } \\
\text { 女子 }\end{array}$ & $\begin{array}{l}15 \\
15\end{array}$ & $\begin{array}{l}30.8 \pm 6.0 \\
27.6 \pm 6.0\end{array}$ & \\
\hline \multirow{3}{*}{ 握力 (kg) } & ラダー & $\begin{array}{l}\text { 男子 } \\
\text { 女子 }\end{array}$ & $\begin{array}{l}7 \\
8\end{array}$ & $\begin{array}{l}5.6 \pm 1.3 \\
5.4 \pm 1.3\end{array}$ & \\
\hline & サーキット & $\begin{array}{l}\text { 男子 } \\
\text { 女子 }\end{array}$ & $\begin{array}{l}18 \\
13\end{array}$ & $\begin{array}{l}5.8 \pm 1.3 \\
5.5 \pm 1.3\end{array}$ & \\
\hline & 自由遊び & $\begin{array}{l}\text { 男子 } \\
\text { 女子 }\end{array}$ & $\begin{array}{l}15 \\
15\end{array}$ & $\begin{array}{l}5.4 \pm 1.3 \\
4.7 \pm 1.3\end{array}$ & \\
\hline \multirow{3}{*}{ 長座体前屈（cm） } & ラダー & $\begin{array}{l}\text { 男子 } \\
\text { 女子 }\end{array}$ & $\begin{array}{l}7 \\
8\end{array}$ & $\begin{array}{l}24.3 \pm 6.8 \\
22.8 \pm 6.7\end{array}$ & \\
\hline & サーキット & $\begin{array}{l}\text { 男子 } \\
\text { 女子 }\end{array}$ & $\begin{array}{l}18 \\
13\end{array}$ & $\begin{array}{l}22.1 \pm 6.8 \\
23.9 \pm 6.7\end{array}$ & \\
\hline & 自由遊び & $\begin{array}{l}\text { 男子 } \\
\text { 女子 }\end{array}$ & $\begin{array}{l}15 \\
15\end{array}$ & $\begin{array}{l}25.0 \pm 6.8 \\
23.3 \pm 6.7\end{array}$ & \\
\hline
\end{tabular}




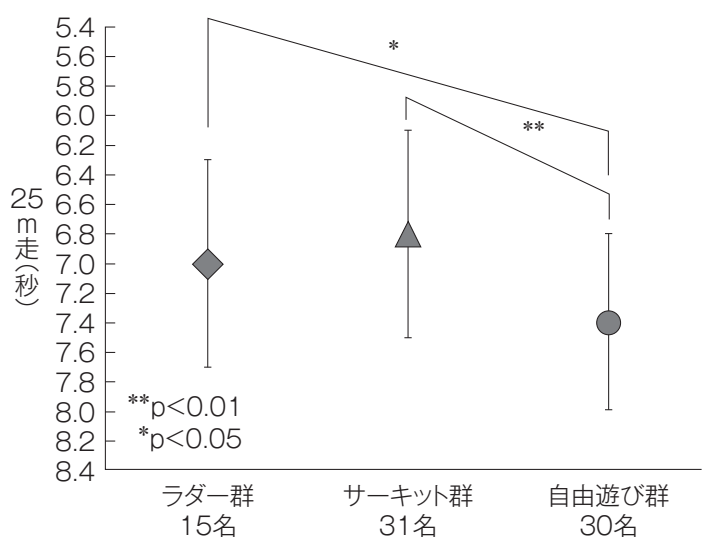

図 1 プレテストを共変量とした共分散分析による 25 $\mathrm{m}$ 走ポストテストの調整後の平均值及びフィッ シャーの LSD 検定による多重比較の結果

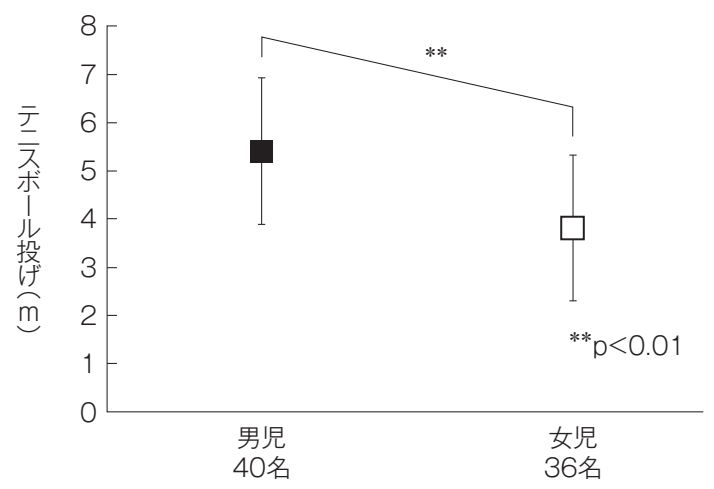

図 3 プレテストを共変量とした共分散分析によるテニ スボール投げポストテストの調整後の平均値

テニスボール投げにおいて, 性の主効果（F（1, 64) $=20.674, \mathrm{p}<.01 ）$ は有意であったが，群の 主効果 $(\mathrm{F}(2,64)=2.669, \mathrm{p}>.05)$ と交互作用 $(\mathrm{F}(2,64)=0.466, \mathrm{p}>.05)$ は有意でなかった. 男児の方が女児よりも遠くへ投げるようになった (図 3).

両脚連続跳び越しにおいて, 群の主効果 (F (2, $65)=1.475, \mathrm{p}>.05)$ と性の主効果 $(\mathrm{F}(1,65)=$ $0.000, \mathrm{p}>.05)$ 及び, 交互作用 $(\mathrm{F}(2,65)=1.655$, $\mathrm{p}>.05 ）$ のいずれも有意でなかった.

体支持持続時間において, 群の主効果 $(\mathrm{F}$ (2, $60)=2.401, \mathrm{p}>.05)$ と性の主効果 $(\mathrm{F}(1,60)=$ $0.240, \mathrm{p}>.05)$ 及び, 交互作用 $(\mathrm{F}(2,60)=0.440$, $\mathrm{p}>$.05）のいずれも有意でなかった.

捕球において, 群の主効果 $(\mathrm{F}(2,63)=6.086$,

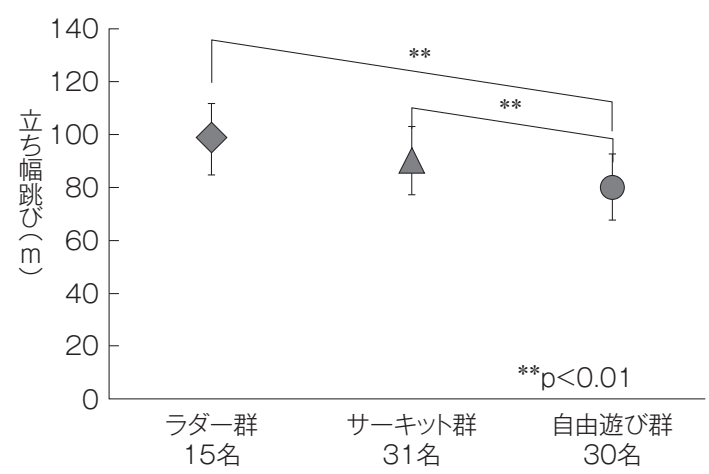

図 2 プレテストを共変量とした共分散分析による立ち 幅跳びポストテストの調整後の平均値及びフィッ シャーの LSD 検定による多重比較の結果

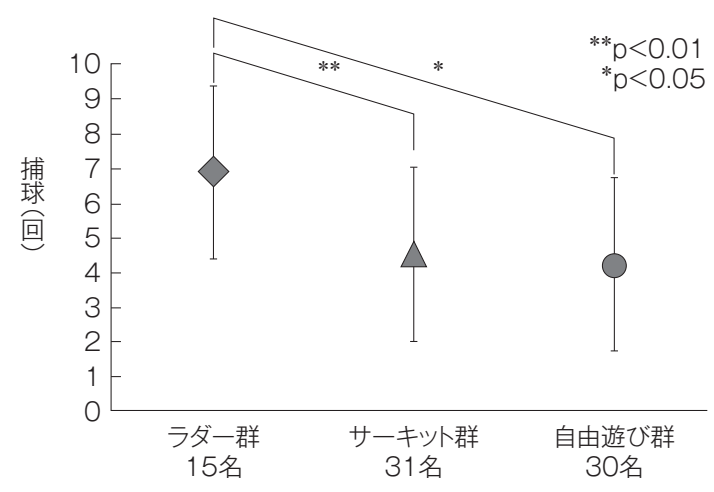

図 4 プレテストを共変量とした共分散分析による捕球 ポストテストの調整後の平均値及びフィッシャー の LSD 検定による多重比較の結果

$\mathrm{p}<.01 ）$ は有意であったが, 性の主効果（F（1, $63)=0.102, \mathrm{p}>.05)$ と交互作用 $(\mathrm{F}(2,63)=$ $2.076, \mathrm{p}>.05)$ は有意でなかった。 そこで, 群 の多重比較を行った結果, 自由遊び群とサーキッ 卜群よりもラダー群の方が多く捕球できるように なった（図 4).

跳び越しくぐりにおいて, 群の主効果 $(\mathrm{F}$ (2, $63)=5.014, \mathrm{p}<.01)$ と交互作用 $(\mathrm{F}(2,63)=$ $5.544, \mathrm{p}<.01)$ が有意であったが，性の主効果 $(\mathrm{F}(1,63)=2.268, \mathrm{p}>.05)$ は有意でなかった. そこで, 単純主効果検定を行った結果, 男児では 自由遊び群よりもラダー群の方が速くなったが, 女児ではサーキット群よりも自由遊び群とラダー 群の方が速くなった（図 5)。なお，いずれの群に おいても有意な性差はみられなかった。 


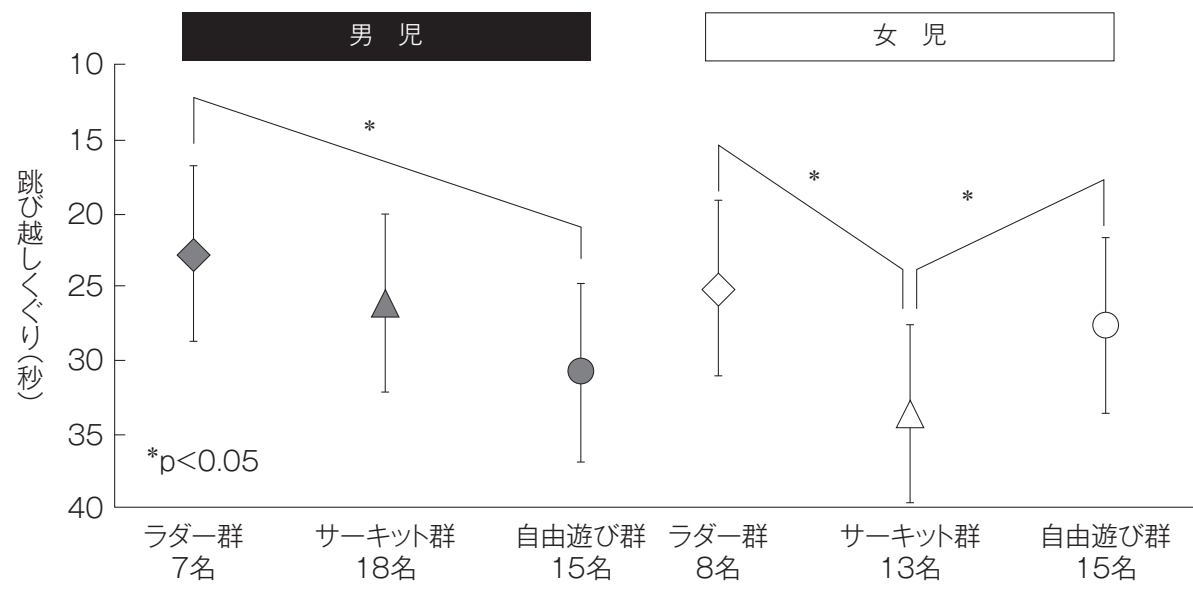

図 5 プレテストを共変量とした共分散分析による跳び越しくぐりポストテストの調整後の平 均値及びフィッシャーの LSD 検定による多重比較の結果

握力において, 群の主効果 $(\mathrm{F}(2,65)=1.558$, $\mathrm{p}>.05)$ と性の主効果 $(\mathrm{F}(1,65)=1.513, \mathrm{p}>$ .05) 及び，交互作用 $(\mathrm{F}(2,65)=0.262, \mathrm{p}>.05)$ のいずれも有意でなかった。

長座体前屈において, 群の主効果 $(F(2,65)=$ $0.212, \mathrm{p}>.05)$ と性の主効果 $(\mathrm{F}(1,65)=0.072$, $\mathrm{p}>.05)$ 及び，交互作用 $(\mathrm{F}(2,65)=0.565, \mathrm{p}>$ .05）のいずれも有意でなかった.

\section{IV 考察}

本研究は, いかなる運動指導よりも, 指導者が 関与しない自由遊びの方が体力・運動能力を高め るのか, それとも, 内発的動機づけを重視した多 様な経験をさせる運動指導であれば，自由遊びよ りも体力・運動能力を高めるのかを明らかにする ために, 多様な運動課題を行うサーキット群ある いはラダー群と, 自由遊び群を比較することを目 的とした。

群間に差がみられたのは, $25 \mathrm{~m}$ 走, 立ち幅跳び, 捕球, 跳び越しくぐりであった.

$25 \mathrm{~m}$ 走においては, 自由遊び群よりもラダー 群およびサーキット群の方が速く走れるように なった．宮口ほか（2010）は幼児期のラダー運動 が走能力を高める運動遊びとして有効であり, 男 児ではかけ足が，女児ではグーパージャンプおよ びひねりジャンプが走能力と高く関連しているこ とを明らかにしている。 今回のラダー課題におい
ても，かけ足拉よびグーパージャンプ，ひねりジャ ンプが含まれていることから, 同様に走能力を向 上させたと考えられる，宮丸（1976）は，ピッチ は調整力における敏捷性に依存し, 幼児期でも成 人に近い能力を有していることを報告している. 4 歳から 5 歳の神経系の発達の著しい時期に, 腕 と脚の協応性や, 筋と神経の反応連携, 重心移動 に関する多様な経験が走能力に関わってくること が推察される。一方, サーキット遊びにおいて, 円盤 4 足歩行において走動作と同様に, 右足と左 手, 左足と右手を同時に前方へ出す動作が出現し ていた，また，網くぐりでは「はう」動作や「膝 立ち」で進む動作が出現していた。このことが走 能力の向上に貢献していると思われる.

立ち幅跳びにおいて, 自由遊び群よりもラダー 群およびサーキット群の方が遠くに跳ぶように なった，幼児の立ち幅跳びの指導ポイントとし て, 踏み切り時の深い沈み込みや上肢の振り上げ 動作などが重要とされており（中野ほか，2012）, サーキット遊びにおけるフットドームから落ちそ うになった時に腕でバランスを取りながら重心を 深く沈みこませ踏ん張る動作が出現していた。 ラ ダー運動においては，グーパージャンプやスラー ロームジャンプにおいて両足を揃えたジャンプ動 作が多く含まれていたことから，遠くに跳ぶ能力 が最も向上したと考えられる。これらに対し, 自 由遊びにおいては，ケンパや石蹴りなどを選択し ないかぎり, 連続したジャンプを伴った活動が行 
われた可能性は低く, 遠くへ跳ぶ力があまり向上 しなかったと考えられる.

捕球については, サーキット群よりもラダー群 の方が多く捕球できるようになった。 ラダー運動 を実施している際，フラフープを投げられる環境 下にあったため, フラフープを真上に投げ，落ち てきたときにキャッチする運動遊びを頻繁に行う 姿が観察された。飛んでくる対象物と距離感, 飛 んでくる方向やスピードなどの空間やタイミング を認知する運動感覚が刺激され, 飛んできた物を 捕るために必要な調整力が発達したと考えられ る。「うける, 捕る」動作は「歩く」「走る」「運ぶ」 「動かす」等の日常的な動作とは異なるため, 投げ る物があり，投げられる環境が整わない限り出現 しにくい(杉原ほか, 2011). したがって,サーキッ 卜遊びには捕る動作が含まれていなかったが，捕 る動作を学習しやすい環境下にあったラダー群の 方が, より多く捕ることができるようになったと 推察される.

跳び越しくぐりについて, 男児では自由遊び群 よりもラダー群の方が速くなったが, 女児では サーキット群よりも自由遊び群とラダー群の方が 速くなった，跳び越しくぐりはゴムを跳び越して くぐる動作の反復運動であり, ジャンプ動作とリ ズム感覚が関与している，男児においては，ラ ダー運動ではグーパージャンプやスラロームジャ ンプ，ケンパジャンプ，ひねりジャンプが含まれ ており, 跳び越しくぐりの能力が向上したと考え られる，女児においては，リズムへの適応が関与 していると考えられる. ラダー運動は子どもたち のリズム反応を引き出す上で有効とされており (宮口ほか, 2010)，自由遊びにおいては，お手玉， まりつき, ゴム跳び, 縄跳び等のリズムを伴った 運動遊びを選択することが多かった。しかし， サーキット遊びの中にはリズム的な要素の運動遊 び項目がなかったことから，女児においては，ラ ダー群および自由遊び群の方がより跳び越しくぐ りの能力が高められたと考えられる.

幼児の動作を分類すると「体を移動する動き」, 「体のバランスをとる動き」,「用具を操作する動 き」の 3 種類に分けられる. ラダー運動やサー キット運動が自由遊びよりも有効であった項目 は, $25 \mathrm{~m}$ 走, 立ち幅跳び, 跳び越しくぐりといっ
た「体を移動する動き」と，捕球の「用具を操作 する動き」であった。内発的動機づけを重視した 多様な経験をさせる運動指導によって, 子どもの 主体的で自発的な遊びが出現し, 指導者が関与し ない自由遊びよりも「体を移動する動き」および 「用具を操作する動き」を高めることが示された。

ただ，これらの効果が，サーキットやラダーと いう課題による影響が大きいのか, 内発的動機づ けを重視したことが大きいのか，あるいは，両方 の相乗効果によるのかは, 今後検討する必要があ る.

\section{$\mathrm{V}$ 結 論}

内発的動機づけを重視した, 多様な運動課題を 経験させるサーキット遊び，および，ラダーを用 いた運動プログラムは, 指導者が関与しない自由 遊びと比較して，「体を移動する動き」および「用 具を操作する動き」を高めることが示された.

\section{文献}

Deci, E. L.（1980）内発的動機づけ，安藤延男，石田梅 男訳, 誠信書房, 60-70

Deci, E. L. and Ryan, R. M. (1985) Intrinsic Motivation and Self-determination in Human Behavior, Plenum Press

伊藤豊彦 (2011) スポーツ参加と動機づけ, 杉原隆編, 生涯スポーツの心理学一生涯発達の視点からみ たスポーツの世界一, 福村出版, 67-77

近藤充夫（1995）幼児のこころと運動, 教育出版,

宮口和義, 出村懭一, 蒲真理子, 鵜沢典子 (2010) 幼 児におけるラダー運動の成就度の年代差・性差お よび走能力との関係, スポーツパフォーマンス研 究, 2, 1-11

宮丸凱史（1976）走る, 浅見俊雄，石井喜八，宮下充 正, 浅見高明, 小林寛道編著, 身体運動学概論, 大修館書店, 153-190

文部科学省（1997）生涯にわたる心身の健康保持増進 のための今後の健康に関する教育及びスポーツ 振興の在り方について（保健体育審議会答申）, http://www.mext.go.jp/b_menu/shingi/old_chu kyo/old_hoken_index/toushin/1314691.htm（参 照日：2016年 6 月 26 日)

森司朗, 杉原隆, 吉田伊津美, 筒井清次郎, 鈴木康弘, 
中本浩揮（2011）幼児の運動能力における時代推 移と発達促進のための実践的介入, 平成 20-22 年 度文部科学省科学研究費補助金（基盤研究 $\mathrm{B}$ ) 研 究成果報告書

中本浩揮（2011）青年・成人期の運動発達の特徵とス ポーツ技能の熟達, 杉原隆編, 生涯スポーツの心 理学一生涯発達の視点からみたスポーツの世 界一, 福村出版, 108-120

中野貴博, 春日晃章, 村瀬智彦 (2012) 幼児期の走 · 跳・投動作獲得に関する質的量的評価の信頼性・ 妥当性一項目反応理論を適用した質的評価の検 討一, 東海保健体育科学, 34, 13-22

Smoll, F. and Smith, R. 著, 市村操一監訳（2008）ジュ ニアスポーツの心理学, 大修館書店

杉原隆 (2014a) 遊びとしての運動の重要性, 杉原隆・ 河邊貴子編, 幼児期に扮ける運動発達と運動遊び の指導一遊びのなかで子どもは育つ一, ミネル ヴァ書房, 31-44

杉原隆（2014b）幼児期の発達的特徵に応じた運動指 導, 杉原隆・河邊貴子編, 幼児期における運動発 達と運動遊びの指導一遊びのなかで子どもは育 つ一，ミネルヴァ書房， 45-63

杉原隆, 森司朗, 吉田伊津美, 近藤充夫 (2004) 2002 年の全国調查からみた幼児の運動能力, 体育の科 学, 54, 161-170

杉原隆, 吉田伊津美, 森司朗, 中本浩揮, 筒井清次郎,
鈴木康弘, 近藤充夫（2011）幼児の運動能力と基 礎的運動パターンとの関係, 体育の科学, $61,455-$ 461

杉原隆, 吉田伊津美, 森司朗, 筒井清次郎, 鈴木康弘, 中本浩揮, 近藤充夫 (2010) 幼児の運動能力と運 動指導ならび性格との関係, 体育の科学, $60,341-$ 347

幼坚運動能力研究会 (2011) MKS 幼览運動能力検査, http://youji-undou.nifs-k.ac.jp/ (参照日 : 2016 年 6 月 26 日)

吉田伊津美（2014）運動発達に関係する園環境と家庭 環境, 杉原隆, 河邊貴子編, 幼児期における運動 発達と運動遊びの指導一遊びのなかで子どもは 育つ一, ミネルヴァ書房, 73-82

吉田伊津美, 森司朗, 筒井清次郎, 鈴木康弘, 中本浩 揮（2015）保育者によって観察された基礎的運動 パターンと幼児の運動能力との関係, 発育発達研 究, $68,1-9$

吉田伊津美, 杉原隆, 森司朗 (2004) 保育形態䢍よび 運動指導が運動能力に及ぼす影響, 日本保育学会 第 57 回大会発表要旨集, 526-527

吉田伊津美，杉原隆，森司朗（2007）幼稚園における 健康・体力づくりの意識と運動指導の実態, 東京 学芸大学紀要総合教育科学系, 58, 75-80

(受付 : 2017 年 2 月 16 日, 受理 : 2017 年 10 月 17 日)
内田 智子（うちだともこ）

愛知教育大学大学院教育学研究科博士課 程

専門は, 発育発達学, スポーツバイオメカニクス, スポー ッ方法学.

幼児期における体力・運動能力向上につながる運動プラグ ラムの在り方とその指導方法をテーマとして研究を行って いる. 